\title{
LEDER
}

\section{Didaktikken - et svar på universitetspædagogiske udfordringer?}

\author{
Jens Jørgen Hansen, lektor ved Syddansk Universitet.
}

Dette nummer af Dansk Universitetspædagogisk Tidsskrift tematiserer didaktiske problemstillinger i universitetspædagogikken. Didaktikken kan generelt set betragtes som en videnskab, der kvalificerer underviseres overvejelser over og valg af undervisningens hvad, hvorfor, hvem og hvordan. Didaktikken forholder sig hermed til kendte universitetspædagogiske udfordringer:

- professionalisering af undervisningen og dens aktiviteter

- fagenes dynamiske udvikling med stigende fokus på relevans, anvendelsesorientering og kobling til problemstillinger og professioner i samfund, økonomi og arbejdsmarked

- det løbende arbejde med at udvikle undervisningen, dens arbejdsformer og metoder med fokus på progression i uddannelsesforløbet

- sammenhængen mellem de studerendes oplevelse af undervisningen, deres tilgange til læring og deres læringsudbytte.

Dette nummers artikler belyser forskellige problemstillinger og didaktiske svar i forhold til flere af disse universitetspædagogiske udfordringer.

Ane Qvortrup og Tina Bering Keiding skriver i "Undervisningens vidensdomæner: erfaring, didaktik og uddannelsesvidenskab" om god undervisning, didaktiske valg og undervisningens begrundelser. Artiklen går ind i undervisningens didaktiske værksted, hvor der træffes beslutninger om mål, indhold, metoder og teknologier og undersøger, hvordan disse valg må træffes i relation til den konkrete undervisningspraksis, fordi den er dynamisk, og fordi dens forudsætninger og muligheder hele tiden er i forandring. Grundlaget for at træffe didaktiske beslutninger finder forfatterne i de tre vidensdomæner: erfaringer, didaktik og uddannelsesvidenskab. De tre vidensdomæner bidrager hver især til at undervisere kan træffe kvalificerede og begrundede didaktiske valg. Erfaringsviden er handlemåder opsamlet gennem underviserens egne erfaringer med undervisning og inspiration fra de konventioner, der ligger i underviserens institution og profession. Didaktikken er kendetegnet ved en mangfoldighed af teorier og beskrivelser af undervisning, der tilbyder en række "refleksionsprogrammer" for de undervisningsmæssige valg. Den empiriske uddannelsesvidenskab bidrager med viden og hypoteser om, hvad der virker i undervisningen. 
Lisanne Wilken og Hanne Tange skriver om kandidatuddannelsernes progression i artiklen "Internationalisering og progression". Ideen om progression handler om en fremadskridende opbygning af specialiseret viden inden for et fagområde. Progressionsideen og dens mulighed for faglig dybde er i disse år udfordret fra bl.a. tværfaglige uddannelsesforløb og internationale uddannelser, hvor studerende kommer med differentierede grunduddannelsesforløb. Problemet viser sig ved, at der er større afstand mellem undervisernes og de studerendes fagligheder. Artiklen peger på, at det $\mathrm{i}$ stigende grad er en didaktisk opgave at eksplicitere, hvilken viden de enkelte uddannelser retter sig mod, og synliggøre uddannelsens særlige akademiske praksisser og arbejdsformer.

Tine Lynfort Jensen skriver endvidere om progression i "Progression og innovation hvordan kan de to begreber berige hinanden og universitetsundervisning?". Artiklen tematiserer innovationsbølgen, der ruller ind over uddannelsessystemet i disse år, en bølge som understreger behovet for at bryde grænser mellem fag, universitet og omverden. Forfatteren underviser i innovationsfag, hvor de studerende har til opgave at udvikle innovative ideer med afsæt i deres viden, faglighed og erfaringer. I den didaktiske planlægning bliver det derfor vigtigt for underviseren at vide, hvem de studerende er, og hvilken viden og hvilke erfaringer de kan aktivere i undervisningen. Artiklen præsenterer en metode til kompetenceafklaring, hvor de studerende i form af en 'kompetenceprofil' beskriver deres uddannelsesmæssige og erfaringsmæssige kompetencer: hvem er jeg, hvad vil jeg, og hvem kender jeg.

Anker Helms Jørgensen tager også fat på de studerende og deres forudsætninger i artiklen "Kan diplomstuderende læse en peer-reviewet artikel i den første uge?" Her undersøges, om de studerende kan læse en peer-reviewet artikel og skrive et abstract af den, og hvad deres holdning er til det. Artiklen tematiserer det didaktiske spørgsmål: valg af litteratur - undervisningens 'hvad'. Skal de studerende præsenteres for lærebogens overblik og veldisponerede formidling af et fagområde eller forskningsartiklens korte og stærke, faglige fokus, der afspejler forskerens videnskabelige arbejdsproces i forholdet mellem problem, teori, metode og præsentation af resultater. De studerende skal også møde forskningsartiklen, er forfatterens svar. Den didaktiske opgave er her at stilladsere de studerendes læsning i form af refleksionsspørgsmål om artiklens retorik, metode og teori.

Lotte Dyhrberg O’Neill, Mette Krogh Christensen, Maria Cecilie Vonsild og Birgitta Wallstedt skriver i artiklen "Program specific admission testing and dropout for sports science students: a prospective cohort study" om rekruttering af studerende og udfordringer $i$ at lave det rette 'match' mellem studerendes forventninger og valg af uddannelsesforløb. Konteksten er sundhedsvidenskabsstudiet, hvor man eksperimenterer med optagelsesforløb, som kan dæmme op for frafald. Man har udviklet et 
koncept, der har fokus på studerendes personlige forventninger til studiet og valg af studerende, der er aktive, informerede og involverede i deres valg af studie. Konceptet består i at bevidstgøre de studerende om studiets kernekompetencer, give studerende mulighed for at teste sig i forhold til disse kompetencer for til sidst at vælge de studerende, der bedst lever op til studiets specifikke kompetencer.

Lotte Bøgh Andersen og Heidi Houlberg Salomonsen tematiserer i "Giver kvinder og mænd forskellige karakterer? Køn og karaktergivning på universitetet" spørgsmålet om vejledning af de studerende med fokus på de studerendes ønsker i vejledningssituationen. Artiklen behandler dog ikke vejledningsdidaktik, men mere spørgsmålet om, hvorvidt kvinder og mænd giver forskellige karakterer som følge af forskellige vejledningsstrategier.

Didaktikken og dens grundspørgsmål - undervisningens hvad, hvorfor, hvem og hvordan - synes i stigende grad at være et omdrejningspunkt for udvikling af kvalitet $\mathrm{i}$ universitetsundervisningen og håndtering af universitetspædagogiske problemstillinger og udfordringer. 